\title{
The Impact of the Integration between the Relevance and Reliability of Accounting Information (AI) in the Level of Accounting Disclosure in Jordanian Industrial Firms
}

\author{
Omar Fareed Shaqqour ${ }^{1}$ \\ ${ }^{1}$ Accounting Department, Faculty of Economics and Administration Sciences, Zarqa University, Jordan \\ Correspondence: Dr. Omar Fareed Shaqqour, Accounting Department, Zarqa University, Jordan. P.O. Box \\ 132222, Zarqa 13110, Jordan. E-mail: oshaqqour@zu.edu.jo
}

Received: March 21, 2018

Accepted: April 10, 2018

Online Published: April 30, 2018

doi:10.5539/ijef.v10n6p97

URL: https://doi.org/10.5539/ijef.v10n6p97

\begin{abstract}
This study aims to measure the effect of the integration between the relevancy and reliability of AI in improving the level of accounting disclosure in Jordanian industrial firms listed on the ASE, by measuring the effect of the integration between the relevancy and reliability of AI in raising the level of compulsory and voluntary disclosure, because the accounting disclosure is important for decision makers and beneficiaries to make there suitable decisions, this study try to determinate the effect of the integration between the relevancy and reliability of AI, which is characterized by good AI, in assess whether disclosure is important or unimportant, and to determinate the role of increasing the relevancy and the reliability of AI on improves the level of compulsory and voluntary accounting disclosure.

The study sample was 50 firms selected randomly from industrial firms listed on the ASE, and the study used a regression analysis method to test hypotheses.

The study concluded that there isn't affect on the degree of availability of Integration between the relevancy and reliability and the level of compulsory accounting disclosure in industrial firms listed on the ASE. Whereas, the results of the study showed that there is an effect on the degree of availability of Integration between the relevancy and reliability and the level of voluntary accounting disclosure in industrial firms listed on the ASE. Which means that the difference between the industrial firms in the level of voluntary accounting disclosure is due to the degree of availability of Integration between the relevancy and reliability of AI.
\end{abstract}

Keywords: characteristics of the AI quality, compulsory disclosure, and voluntary disclosure

\section{Introduction}

\subsection{Introduce the Study}

This study aims to measure the effect of the integration between the relevancy and reliability of AI in improving the level of accounting disclosure in Jordanian industrial firms listed on ASE, because the accounting disclosure is important for decision makers and beneficiaries to make there suitable decisions, this study try to determinate the effect of the integration between the relevancy and reliability of AI, which is characterized by good AI, on improves the level of compulsory and voluntary accounting disclosure.

Relevancy and reliability are the two main characteristics of the quality of AI. These characteristics reflect the characteristics of good AI, and the basis for evaluating the quality of AI. Identifying these characteristics helps decision makers to make appropriate decisions (Shirazi, 2000). These characteristics that must be met in the AI of the prepared financial statements, will Benefit decision makers and make AI more quality, which means, that the good AI is the most useful information for the decision makers. It should be noted that these characteristics, which must be met in the AI, are of great value to the financial reporting preparers, because it helps in assessing the quality of the AI prepared (Schroeder, 2006).

The Relevance of the information is an important characteristics, which ought to be applied in the AI, and the relevancy is define as the ability of AI to change the decision of the users or the decision makers and affect on it, in other words, the ability of the information to make a difference in decision making. It helps to predict current and future events, to assist the process of confirming or correcting past expectations, and to be made available in 
appropriate time (Kiso, 2014). Providing a relevance information alone is not enough, the information must also be reliable. The reliability is meaning that the AI must be free from error and bias, and is presented in a safe and honest manner. AI that is reliable should lead to the same outputs and results when using the same measurement methods, expressed honestly and truthfully about the financial events that are measured, so that there is consistency between the financial numbers and the economic and financial events, and not include preference of one of the beneficiaries on the other beneficiaries (Dahmash, 1990).

The researcher believes that relevancy and reliability are complementary characteristics, and the availability of these two features in AI is important and necessary to make this information more useful and quality, but in some cases, it may difficult for users of AI and decision makers to obtain information that is relevance and reliable in the same time, thus they balance between the two characteristics and may prefer one of them over the other. In the study (Al-Jwher, 2011) showed that there are restrictions that affect on the relevancy and reliability characteristics, such as balancing the cost and benefit: that the benefits obtained from the information should be greater than the costs incurred in providing this information, in addition of balancing the qualitative characteristics: the balance between relevancy and reliability characteristics in a comprehensive manner, in order to achieve the objectives of the financial statements.

Accounting disclosure refers to the information published by the management to third parties that use financial reporting to meet their various needs related to the entity (Al-Jayyousi, 2003), and it is defined as providing the data and AI to its users in a complete, correct and appropriate manner, to assist them in making decisions (Al-Otaibi, 2009), and may be defined as the publication of necessary accounting data or information, that is not misleading and does not affect on the efficiency of the information which is included in the financial reports (Al-Salihat, 2008), and it means the inclusion of financial reports all necessary information that give users of these reports a clear and correct vision of the entity (Al-Qattan, 2008).

The researcher note that the previous definitions focused on the need to present information in a way that reflects the position of the firm without misleading, so that the users of this information can rely on them to make the right decision, but they differed between them about the amount of information that should provide to users. He also note that the disclosure is the spirit of any financial market and the basis of its.

In the opinion of the researcher, the disclosure of accounting policies will help to explain the financial statements of any company, and therefore disclosure will remain one of the important issues that occupy the accounting theory, and the intellectual development of accounting disclosure touch the efforts of many accountants in this scope, in addition to the efforts of scientific and professional organizations. In this sense, accounting theory has witnessed an increasing interest in accounting disclosure and its relation to the credibility of financial reports and statements.

There are two types of accounting disclosure, compulsory or legal disclosure: disclosure of information required by law, and voluntary disclosure: disclosure of information that did not require by law. In other words, if the law requires publication of this information, it is called compulsory disclosure, but if the law does not require publication of this information, it is called voluntary disclosure (Emera, 2011).

The study objective is to know the effect of the availability of the characteristics of AI on improving the level of accounting disclosure in Jordanian industrial firms by measuring the impact of the integration between the relevancy and reliability of $\mathrm{AI}$ in improving the level of accounting disclosure.

\subsection{The Study Problem}

The characteristics of the AI quality are considered to be the basis for assessing the quality of AI, which are beneficial to the decisions makers and make AI of high quality. These characteristics help decisions makers make appropriate decisions (Shirazi, 2000). The two types of disclosure (compulsory disclosure and voluntary disclosure) play an important role in providing the necessary and non-misleading information to beneficiaries. The determination of characteristics of the AI quality, which is characterized by good AI, helps decision makers and beneficiaries to assess whether disclosure is important or unimportant (Shirazi, 2000).

The research gap appears in the importance of accounting disclosure for decision makers and beneficiaries to make there suitable decisions, this study try to determinate the effect of the integration between the relevancy and reliability of AI, which is characterized by good AI, in assess whether disclosure is important or unimportant, and to determinate the role of increasing the relevancy and the reliability of AI on improves the level of compulsory and voluntary accounting disclosure

Therefore, the problem of the study is the effect of the integration between the relevancy and reliability of AI on improves the level of compulsory and voluntary accounting disclosure in Jordanian industrial firms. 


\subsection{The Importance of Study}

The importance of the study is Identifies in the role of compulsory and voluntary accounting disclosure in corporate firms in general and in the industrial firms in particular, in supporting the Jordanian economy, by increasing confidence in the financial reports, because providing full disclosure is important for all beneficiaries, interest parties.

The research will present to the users of the AI some of the field results related to the effect of the integration between the relevancy and reliability of the AI in improving the level of compulsory and voluntary accounting disclosure in the Jordanian industrial joint stock firms.

\subsection{Previous Studies}

(Corona et al., 2014). This study aimed to demonstrate the interaction between competitive banks and the quality of AI and its impact on banks' behavior in the face of risks. This study showed that improving the quality of AI increases the risk in simple competitions but does not influence hyper competition. And (Hamadh, 2014), the aim of this study was to Know the effect of voluntary disclosure on the financial reports quality, and to conduct the study objective, the research improve a questionnaire, that contain disclosure components: information of the firm, firm activity and future plains, information of the stock, management information, environmental and social responsibility, ratios and results of non-financial and financial analyzes, firm R\&D costs, employees information, and corporate governance information. The study result shows that there is an affect of the optional disclosure components on the financial reports quality, and study recommended that firms should adopt the voluntary disclosure. Thus, the study (Ben Aishy \& Omri, 2011), The study examined the impact of the application of the rules of governance on accounting disclosure and the quality of financial reports, the case of Algerian corporate companies, and the study found that the elements of disclosure and transparency are available to all stakeholders and interest parties. In addition to the study (Ameer, 2011), this study aimed to examine the relationship between the level of accounting disclosure and the cost of capital on industrial companies listed on the ASE. The main results of the study were that industrial companies offer a level of voluntary accounting disclosure at a rate of $28 \%$, if the tools of communication with investors are taken into consideration, and $45 \%$ if the tools of communication with investors are not taken into consideration. (Abu Hammam's, 2009) study aims to know the effect of the application of the rules of governance on accounting disclosure and the quality of financial reports in the Palestine Securities Exchange. The study concluded that the application of the rules of governance contributed to enhancing the role of accounting disclosure and the quality of financial reports. (Hossain \& Hammami, 2009), this study aimed to test the determinants of voluntary disclosure in the annual reports of companies listed on the Qatar Exchange. The annual reports of 25 companies listed on the Qatar Exchange were studied, and the study found that the age of the company, its size, and the complexity of its operation, are important variables in explaining the difference in the level of voluntary disclosure between companies, but the profitability of the company is not considered an important variable to explain the difference in the level of voluntary disclosure. Finally, (Al-shamy, 2009) study the study aims to measure the effect of the qualitative characteristics of AI on the financial reports quality issued by banks on Yemen, the study result shows that there is a high effect on the primary characteristics of AI on the financial reports quality.

The researcher note that, some of the previous studies focused on the relationship between the characteristics of the quality of AI and other variables, while other previous studies focused on the relationship between compulsory or voluntary accounting disclosure and other variable, the researcher did not find any previous studies, that measured the relationship between the characteristics of the quality of AI and accounting disclosure. This study is attempt to measure the effect of the integration between the relevancy and reliability of AI in improving the level of compulsory and voluntary accounting disclosure in Jordanian industrial firms.

\subsection{Study Hypotheses}

The study consists of the following hypotheses:

HO 1: There is no effect of the integration between the relevancy and reliability of AI in improving the level of compulsory accounting disclosure in Jordanian industrial firms.

HO 1-1: There is no effect of the relevancy of AI in improving the level of compulsory accounting disclosure in Jordanian industrial firms.

HO 1-2: There is no effect of the relevancy of AI in improving the level of voluntary accounting disclosure in the Jordanian industrial firms.

HO 2: There is no effect of the integration between the relevancy and reliability of AI in improving the level of voluntary accounting disclosure in the Jordanian industrial firms. 
HO 2-1: There is no statistically effect of the reliability of AI in improving the level of compulsory accounting disclosure in the Jordanian industrial firms.

HO 2-2: There is no effect of the reliability of AI in improving the level of voluntary accounting disclosure in the Jordanian industrial firms

\section{Methods of Study}

\subsection{Study Sample}

The study population consists of all industrial firms listed on the ASE, but the sample of the study includes 50 firms from industrial firms listed on the ASE for 2016.

\subsection{Data Collection Sources}

The study data were collected by reviewing the literature and theoretical studies that related to the study, by reviewing the published books, researches and articles, in addition to using the Internet. The data was also collected through the financial report of the industrial firms listed on the ASE for 2016 to determine the level of compulsory accounting disclosure and voluntary accounting disclosure, and the study also used the questionnaire method to determine the availability of the relevancy and reliability a and in the Jordanian industrial joint stock firms industrial firms.

\subsection{Study Variables and How to Measure Them}

The study variables consist of two dependent variables: the level of compulsory accounting disclosure and the level of optional accounting disclosure, and one independent variable: the degree of availability of the relevancy and reliability.

(1) Level of Compulsory Accounting Disclosures:

The level of compulsory accounting disclosure was measured by the (Al-Jayyousi, 2003) index by giving the number 1 if the firm discloses the item and the number 0 if the firm does not disclose the item, then the following equation is applied:

Level of compulsory disclosure $=[$ Number of items disclosed $/$ number of all items $] * 100$

(2) Level of voluntary accounting disclosure:

The level of voluntary disclosure is measured by the (Hossain \& Hamammi, 2009) Index, by giving the number 1 if the firm discloses the item and the number 0 if the firm does not disclose the item, then the following equation is applied:

Voluntary disclosure level $=[$ Number of items disclosed $/$ number of all items $] * 100$

(3) The degree of availability of the relevancy and reliability

The degree of availability of the relevancy and reliability was measured by a questionnaire presented to two internal auditors in industrial firms listed on the ASE. The relevance was measured by questions (1-5). Reliability was measured by questions (6-10).

\subsection{Test the Validity and Stability}

In order to ascertain the internal consistency of the questionnaires and to verify their reliability, the Cronbach's Alpha is used. The calculation of the stability coefficient according to this method indicates stability, stability and dependence. In applying the Cronbach's Alpha test to the questionnaire of the study, (Cronbachs Alpha) to identify the study value of 0.826 , indicating that the questionnaire questions are highly correlated, and that there is a high degree of consistency of all questions.

\section{The Results}

\subsection{Test Hypotheses and Discuss Results}

The researcher used EXCEL and SPSS to analyze the data, and identify the descriptive statistics of the study variables, and the results of the hypothesis test. Table 1 shows the descriptive statistics of the variables of the study. Table 2 shows the results of the hypotheses of the study. 
Table 1. Descriptive statistics

\begin{tabular}{cccccc}
\hline & $\mathrm{N}$ & Minimum & Maximum & Mean & Std. Deviation \\
\hline Integration between the relevancy and reliability & 50 & $40 \%$ & $95 \%$ & $70 \%$ & .17 \\
Relevancy & 50 & $30 \%$ & $90 \%$ & $64 \%$ & .18 \\
Reliability & 50 & $50 \%$ & $100 \%$ & $76 \%$ & .16 \\
Compulsory accounting disclosure & 50 & $79 \%$ & $96 \%$ & $88 \%$ & .05 \\
Voluntary accounting disclosure & 50 & $52 \%$ & $95 \%$ & $72 \%$ & .15 \\
\hline
\end{tabular}

Table 2. Regression analysis of study hypothesizes

\begin{tabular}{ccccc}
\hline Hypothesis & T & F & T sig & Result of null hypothesis HO \\
\hline HO 1 & 0.933 & 0.871 & 0.355 & accepted \\
HO 1-1 & 0.733 & 0.538 & 0.467 & accepted \\
HO 1-2 & 1.120 & 1.255 & 0.268 & accepted \\
HO2 & 4.247 & 18.038 & 0.000 & rejected \\
HO 2-1 & 3.866 & 14.948 & 0.000 & rejected \\
HO 2-2 & 4.422 & 19.555 & 0.000 & rejected \\
\hline
\end{tabular}

HO1: There is no effect of the integration between the relevancy and reliability of AI in improving the level of compulsory accounting disclosure in Jordanian industrial firms

Table 1 shows that the availability of Integration between the relevancy and reliability in industrial firms listed on the ASE is 70\%, which is good, and also the table shows that there was a difference between the industrial firms listed on the ASE in the degree of availability of relevancy and reliability, where the highest value was 95\% and the lowest value was $40 \%$. Thus the table shows that the level of compulsory disclosure in industrial firms listed on the ASE was $88 \%$, which is a very good, and the table shows that there was a difference between the industrial firms in the level of compulsory disclosure, where the highest value was $96 \%$ and the lowest value was $76 \%$.

This hypothesis was tested using the simple regression test. Table 2 shows that the results of test the impact of the integration between the relevancy and reliability of AI in improving the level of compulsory accounting disclosure in Jordanian industrial firms, the result shows that the value of P-value sig. $=0.355$, which is more than the level $\alpha=0.05$, thus we accept the null hypothesis and reject the alternative hypothesis, which means that the integration between the relevancy and reliability of AI doesn't affect on improving the level of compulsory accounting disclosure in Jordanian industrial firms.

HO1-1: There is no effect of the relevancy of AI in improving the level of compulsory accounting disclosure in Jordanian industrial firms.

This hypothesis was tested using the simple regression test. Table 2 shows that the results of test the impact of the relevancy of AI in improving the level of compulsory accounting disclosure in Jordanian industrial firms, the result shows that the value of P-value sig. $=0.467$, which is more than the level $\alpha=0.05$, thus we accept the null hypothesis and reject the alternative hypothesis, which means that the relevancy of AI doesn't affect on improving the level of compulsory accounting disclosure in Jordanian industrial firms.

HO1-2: There is no effect of the relevancy of AI in improving the level of voluntary accounting disclosure in the Jordanian industrial firms.

This hypothesis was tested using the simple regression test. Table 2 shows that the results of test the impact of the reliability of AI in improving the level of compulsory accounting disclosure in Jordanian industrial firms, the result shows that the value of P-value sig. $=0.268$, which is more than the level $\alpha=0.05$, thus we accept the null hypothesis and reject the alternative hypothesis, which means that the reliability of AI doesn't affect on improving the level of compulsory accounting disclosure in Jordanian industrial firms.

The result of the previous three hypotheses, which relate to compulsory disclosure, was accepted of the null hypothesis and rejected the alternative hypothesis. This means that the primary characteristics of the quality of AI (relevancy and reliability) in an integrated manner or separately, do not affect on the compulsory disclosure in the industrial firms. This is result according to the researcher's opinion because, compulsory disclosure is obligatory for firms to apply, so the application of firms to compulsory disclosure is not affected by other factors.

HO2: There is no effect of the integration between the relevancy and reliability of AI in improving the level of 
voluntary accounting disclosure in the Jordanian industrial firms.

Table 1 shows that the availability of Integration between the relevancy and reliability in industrial firms listed on the ASE is 70\%, which is good, and also the table shows that there was a difference between the industrial firms listed on the ASE in the degree of availability of relevancy and reliability, where the highest value was 95\% and the lowest value was $40 \%$. Thus the table shows that the level of compulsory disclosure in industrial firms listed on the ASE was $72 \%$, which is a good, and the table shows that there was a difference between the industrial firms in the level of compulsory disclosure, where the highest value was $95 \%$ and the lowest value was $52 \%$.

This hypothesis was tested using the simple regression test. Table 2 shows that the results of test the impact of the integration between the relevancy and reliability of AI in improving the level of voluntary accounting disclosure in Jordanian industrial firms, the result shows that the value of P-value sig. $=0.000$, which is less than the level $\alpha=0.05$, thus we rejected the null hypothesis and accepted the alternative hypothesis, which means that the integration between the relevancy and reliability of AI affect on improving the level of voluntary accounting disclosure in Jordanian industrial firms.

HO2-1: There is no effect of the reliability of AI in improving the level of compulsory accounting disclosure in the Jordanian industrial firms.

This hypothesis was tested using the simple regression test. Table 2 shows that the results of test the impact of the relevancy of $\mathrm{AI}$ in improving the level of voluntary accounting disclosure in Jordanian industrial firms, the result shows that the value of P-value sig. $=0.000$, which is less than the level $\alpha=0.05$, thus we rejected the null hypothesis and accepted the alternative hypothesis, which means that the relevancy of AI affect on improving the level of voluntary accounting disclosure in Jordanian industrial firms.

HO2-2: There is no effect of the reliability of AI in improving the level of voluntary accounting disclosure in the Jordanian industrial firms.

This hypothesis was tested using the simple regression test. Table 2 shows that the results of test the impact of the reliability of AI in improving the level of voluntary accounting disclosure in Jordanian industrial firms, the result shows that the value of P-value sig. $=0.000$, which is less than the level $\alpha=0.05$, thus we rejected the null hypothesis and accepted the alternative hypothesis, which means that the reliability of AI affect on improving the level of voluntary accounting disclosure in Jordanian industrial firms.

The result of the previous three hypotheses, which relate to voluntary disclosure, was rejected of the null hypothesis and accepted the alternative hypothesis. This means that the primary characteristics of the quality of AI (relevancy and reliability) in an integrated manner or separately, affect on the voluntary disclosure in the industrial firms. This is result according to the researcher's opinion because, voluntary disclosure isn't obligatory for firms to ap the quality of AI ly, so the application of firms to voluntary disclosure is affected by other factors, as the quality of AI.

\subsection{Conclusions}

The Conclusions of the study was:

1) The results of the study showed that the level of compulsory disclosure in industrial firms listed on the ASE was $88 \%$, which is a very good, and it showed that there was a difference between the industrial firms in the level of compulsory disclosure, where the highest value was $96 \%$ and the lowest value was $76 \%$, and this consistent with Al-Jayousi (2003) study, which showed that the level of disclosure in Jordanian banks ranged from $52 \%$ to $85 \%$.

2) The results of the study showed that the level of voluntary disclosure in industrial firms listed on the ASE was $72 \%$, which is a good, and it showed that there was a difference between the industrial firms in the level of voluntary disclosure, where the highest value was $95 \%$ and the lowest value was 52\%, where the study (Ameer, 2011), showed that industrial firms offer a level of voluntary accounting disclosure at a rate of $28 \%$, if the tools of communication with investors are taken into consideration, and $45 \%$ if the tools of communication with investors are not taken into consideration

3) The results of the study showed that the degree of availability of Integration between the relevancy and reliability in industrial firms listed on the ASE is $70 \%$, which is good, the degree of availability of the relevancy is $64 \%$, and the degree of availability of reliability is $76 \%$, and also the study showed that there was a difference between the industrial firms listed on the ASE in the degree of availability of relevancy and reliability, where the highest value was $95 \%$ and the lowest value was $40 \%$. 
4) The results of the study showed that there isn't affect on the degree of availability of Integration between the relevancy and reliability and the level of compulsory accounting disclosure in industrial firms listed on the ASE, and this consistent with (Al-shamy, 2009) study, which concluded that there is a high impact on the primary characteristics of AI on the quality of financial reports.

5) The results of the study showed that there is an effect on the degree of availability of Integration between the relevancy and reliability and the level of voluntary accounting disclosure in industrial firms listed on the ASE. Which means that the difference between the industrial firms in the level of voluntary accounting disclosure is due to the degree of availability of Integration between the relevancy and reliability of AI, and this consistent with (Al-shamy, 2009) study, which concluded that there is a high impact on the primary characteristics of AI on the quality of financial reports.

\subsection{Recommendations}

1) The need to increase the interest in providing the quality characteristics of the AI in the Jordanian firms by developing laws that oblige to improve the quality of the AI that the firms preparing.

2) The need for firms listed on the ASE to adopt the concept of voluntary disclosure, and presentation its components in its financial statement.

\section{References}

Al-Jayousi, A. (2003). Level of Disclosure in Annual Reports of Banks. Master Thesis, University of Jordan, Amman, Jordan.

Al-Jwher, K. (2011). The relationship between the characteristics of AI quality and the governance rules of the Board of Directors (An analytical study of the views of accountants and auditors). The Magazine of Economic and Administration, (90).

Al-Salihat, N. (2008). Suggested Strategy for Measurement and Disclosure of Financial Derivatives in Public Shareholding Firms and Their Impact on Investment Risks in Jordan Stock Exchange. Doctoral dissertation, Amman Arab University, Jordan.

Al-Shirazi, A. (1990). Accounting Theory. Kuwait: Al-Sallas for Printing and Publishing.

Ameer, M. (2011). The Relationship between the Level of Accounting Disclosure and the Cost of Capital in Jordanian Industrial Firms. Doctoral dissertation, Amman Arab University, Jordan.

Ben Aishy, A., \& Omri, S. (2011). Application of the Rules of Governance and Its Impact on Accounting Disclosure the Quality of Financial Reports, The Case Study of Algeria. Retrieved from http://iefpedia.com

Corona, C., Nan, L., \& Zhang, G. (2014). AI quality, interbank competition, and bank risk-taking. The Accounting Review, 90(3), 967-985. https://doi.org/10.2308/accr-50956

Hamada, R. (2014). Measuring the impact of voluntary disclosure on the quality of financial reports (field study on the ASE). Jordan Journal of Business Administration, 10(4).

Hossain, M., \& Hammami, H. (2009). Voluntary Disclosure in The Annual Report of an Emerging Country: The Case of Qatar. Corporate Advance in International Accounting, 25. https://doi.org/10.1016/j.adiac.2009.08.002

Kieso, D. E., Weygandt, J. J., \& Warfield, T. D. (2010). Intermediate accounting: IFRS edition (Vol. 2). John Wiley \& Sons.

Naim, D. (1990). Financial Statements and Generally Accepted Accounting Principles, a Scientific and Practical Perspective. Al-Esteshare Office, Amman, Jordan.

Schroeder, R. G., Clark, M. W., \& Cathey, J. M. (2001). Accounting: Theory and Analysis. John Wiley \& Sons.

\section{Copyrights}

Copyright for this article is retained by the author(s), with first publication rights granted to the journal.

This is an open-access article distributed under the terms and conditions of the Creative Commons Attribution license (http://creativecommons.org/licenses/by/4.0/). 